\title{
The Main Benefits of the Implementation of the Quality Management System in Higher Education Institutions in Angola
}

\author{
DOI: 10.12776/QIP.V23I3.1292
}

Nicolay Africano, Ana S. Rodrigues, Gilberto Santos

Received: 07 August 2019 Accepted: 27 November 2019 Published: 30 November 2019

\begin{abstract}
Purpose: The aim of this study is to obtain a diagnosis regarding the implementation of QMS (Quality Management System) according to ISO 9001 in Higher Education Institutions (HEIs) of Angola.
\end{abstract}

Methodology/Approach: The research was conducted through a questionnaire proposed to survey selected 55 institutions. Fifty completed questionnaires were received, representing the sample of this work. The statistical analysis SPSS version 22.0 for Windows was used for the treatment of the data.

Findings: The results of the study show that of the 50 Angolan HEIs surveyed, only $20 \%$ of them have the Quality Management System implemented. As main benefits of the implementation of the QMS in HEIs of Angola, we can highlight: Improvement of the quality of teaching; Improvement of student satisfaction; Improvement of confidence of students and other stakeholders; Improvement in student assessment; Improvement of teacher competences.

Research Limitation/implication: The main limitation of the study lies in the fact that of the 50 Angolan HEIs referred, only 20\% of them have the Quality Management System implemented, which shows that there is still much work to be done in this area.

Originality/Value of paper: Higher education in Angola has had an evolution in terms of demand and access. Due to the quantitative development of higher education in Angola, it is necessary to be accompanied by qualitative growth, which implies the reinforcement of the need for quality management.

Category: Research paper

Keywords: organization context; higher education; ISO 9001; quality planning and organizational processes 


\section{INTRODUCTION}

The continuous development of quality management in organizations was driven on the one hand by competition and on the other hand by growing requirements of the customers (Weckenmann, Akkasoglu and Werner, 2015). In recent years, quality management in Higher Education Institutions (HEIs) in Angola has been the subject of increasing interest motivated by the impact on their performance. The implementation and certification of the Quality Management System (QMS) are nowadays indispensable to any institution because it is seen as a differentiating flag for the institutions of the sector. However, quality is still questioned, and inefficiency of management is identified as a result of bottlenecks in funding, curricula, faculty, and student bodies.

The adoption of a QMS by organizations represents, even in the case of public organizations, a strategic decision that can help improve their overall performance and provide a solid foundation for sustainable development initiatives. On the other hand, risk-based thinking enables organizations to determine the factors likely to cause deviations in their processes and QMS from planned results, implement preventive controls to minimize negative effects, and maximize the opportunities that emerge. In this sense, the implementation of a QMS should seek to instil the principles of quality in the organizational processes according to ISO 9001:2015, of which we highlight: Customer focus; Leadership; Commitment of people; Improvement. The implementation of the QMS in the functional structure of public organizations is now supported by specific initiatives and models such as the Common Assessment Framework (CAF), European Foundation for Quality Management (EFQM), and International Organization for Standardization (ISO) standards, which represent important methodological support. These benchmarks for the implementation of QMS tend to emphasize the importance of the role of the clients in the definition of strategic objectives, the minimization of errors, and bet on the continuous improvement of the processes of supply of products and services. Its current relevance also stems from the fact that efficiency in resource management (including human resources) and customer capture have become central factors in the survival of public organizations, especially in a context of greater competitiveness between educational institutions and simultaneously, the successive budget cuts that Angola is experiencing (Veiga, 2014). In the last decades of the twentieth century, the Angolan government, regardless of its ideological tendency, encountered structural problems stemming from ineffective Higher Education. The transformations that occurred in Higher Education in Angola during the last decade had, as a consequence, the modernization, and administrative reform that the government started to take in order to improve the subsystem, conducted for the effectiveness, efficiency, and quality of the services they provided. In view of this situation, we note the concern of the Angolan State regarding the need to improve the quality of higher education. For this reason, the use of the QMS as a possible way to find the desired quality is invoked. Thus, higher education should develop the potential of each individual and provide 
graduates with the necessary knowledge and skills that promote individual development to be successful in their professions. According to the last President of the Republic of Angola, José Eduardo dos Santos (ANGOP, 2008):

"We must make an evaluation of the implementation of the programs for the reform of the education system and the subsystem of Higher Education to detect the shortcomings and correct them and define the instruments for the materialization of the guidelines emanating from the Government program approved by the voters with a view to improve the quality of teaching, the working conditions of teachers and the management of educational establishments at all levels."

According to Adão do Nascimento, "despite the successes achieved over the years, since the proclamation of national independence, improving quality and expanding the network of institutions of the subsystem of Higher Education is an imperative that is put to the Angolan State" (SEES, 2005). Thus, education is the most determining sector for the future of society. This importance increases with the level of development of the country or the region, in particular because competitiveness requires higher levels of qualification, which are not possible to achieve without the teaching-learning systems being able to meet the needs of the community in quantity and quality (Pires, 2012). The reform and modernization of Higher Education in Angola also depends on the competence and motivation of teachers and researchers. However, the number of teaching and research professionals has often not accompanied the increase in the number of students, which exacerbates the already felt capacity pressure (SEES, 2007). Better working conditions, including transparent and fair recruitment procedures, better initial and continuing professional development, and better recognition and reward of excellence in teaching and research are essential if Angola is to produce, attract, and academic staff you need.

The objective of this work is to highlight the main advantages of the implementation and certification of the QMS in higher education in Angola, its performance and the efficient use of resources for the training of students and the provision of services to the community.

\section{THEORETICAL FRAMEWORK}

\subsection{The Quality Concept}

In a market economy, each organization is competing with others providing the same product. This principle is valid independent of the type of offer, including material goods as well as immaterial services or their combination (Weckenmann, Akkasoglu and Werner, 2015). Although quality management has become a notorious issue since the early 1980s, it is not a modern invention. We can tell the story of quality in many ways. A large number of scholars agree that the concept or philosophy of quality has long existed, disagreeing only with some 
that the concept of quality has existed for hundreds of years, and others speak for thousands of years (António and Teixeira, 2009). Quality Management as a management field is rich with research on different aspects and theories, empirical data from the field and theoretical elaborations. Some of its fundamental aspects are well defined and established through well-known and widely used international management standards such as ISO 9001 and ISO 14001 (Santos, Mendes and Barbosa, 2011). Nowadays, organizations without quality do not survive (Araújo et al., 2019; Santos and Milán, 2013; Santos, Murmura and Bravi, 2019). Hence, there are many organizations that integrate QMS with other Management Systems, namely with Environmental Management System (EMS) and Occupational Health and Safety Management System (OH\&SMS) among others (Carvalho, Santos and Gonçalves, 2018; Santos, Rebelo and Santos, 2017; Ribeiro et al., 2017) seeking to optimize human, material and financial resources (Zgodavová, Zolotova and Roznik, 2011; Costa et al., 2019). These are sustainable organizations. Thus, ISO 9001 is applied in different kinds of organizations all over the world (Ingason, 2015; Santos et al., 2008). It is necessary to build an organisational culture for quality. In general, organisational culture is understood through the deeply embedded values and beliefs shared in an organization. Every organisation has a unique culture. It is almost impossible to achieve excellence unless a suitable culture of quality has been introduced because culture is the driving force of quality. Organisational culture represents an organisation's experiences that have accumulated over the history of the organisation (Zgodavova, Hudec and Palfy, 2017; Araújo et al, 2019). The measurement culture has grown in education, both in education policies and in the practice of schools and teachers (Rodriguez-Mantilla, Fernandez-Diaz and Carrascosa, 2019). Thus, the ISO 9001 implementation in organizations reduces the cost of poor quality (Lee, To and $\mathrm{Yu}, 2009$; Santos and Barbosa, 2006) and increases the organization's chances of gaining work in the private or public sector through the creation of better internal management systems and service quality improvement (McAdam and Canning, 2001; Murmura and Bravi, 2017; Marques et al, 2018). The benefits of implementing the QMS were analysed by several authors, among others (Santos et al., 1996; Santos and Milan, 2013; Fonseca and Domingues, 2018; Bravi, Murmura and Santos, 2019). Among the higher benefits to institutions highlighted by that authors are, namely, the improvement of the institution's image, the introduction of clear procedures for quality, awareness of quality, clarification of responsibilities, reorganization, and improvement of efficiency. It also occurs the return on investment (Santos, Costa and Leal, 2012; Batista and Santos, 2015).

According to the French association for standardization, quoted by (Fey and Gogue, 1983) "the quality of a product or a service is its ability to meet the needs of users". The American Society for Quality (ASQ), quoted by (Kotler and Keller 2006) stats that "quality is the totality of attributes and characteristics of a product or service that affect its ability to meet stated or implied needs". ISO 9000:2015 (IPQ, 2015a) defines "quality as the degree of satisfaction of requirements given by a set of intrinsic characteristics". In the twentieth century, 
the greatest importance attributed to quality led to the investigation, formulation, and publication of various definitions for the concept, highlighting such illustrious authors as Joseph Juran, Philip Crosby, Walter Shewhart, Edwards Deming and Kaoru Ishikawa (António and Teixeira, 2009). Today, many organizations are "searching" for excellence, but not many organizations have been able to achieve this goal, seemingly because management does not have a profound understanding what it really means to be excellent (Dahlgaard-Park and Dahlgaard, 2007). To improve services and to achieve quality and excellence, ideas and a good education system are describet in (Santos et al., 2018; Santos et al., 2019).

\subsection{The Concept of Quality in Higher Education}

Understanding the politics of education reform is crucial to assess the challenges facing the SDG (Sustainable Development Goals) of quality education (Bruns, Macdonald and Schneider, 2019). The aim of all educational systems, nowadays, is to provide quality education (Sánchez, Lupión and González, 2017). Implementation of Quality Management Systems in educational organisations is a fact in many countries. Therefore, it is necessary to obtain evidence of the improvements and changes that the centres have because of the implementation (Rodriguez-Mantilla, Fernandez-Diaz and Carrascosa, 2019). The term "quality" has been used in the most diverse fields of knowledge, including the educational one, although there are substantial differences in its conceptualization, that is, there is no universal definition. The universal is the recognition of quality, both in products and services, as a decisive factor for the development of organizations, in an increasingly competitive world. In the educational context, definitions of the term "quality" focus on various aspects such as customer satisfaction, management, and administration of educational institutions, availability of human, financial and infrastructural resources, since they contribute to the successful accomplishment of the functions of IES (Pires, 2012). For António and Teixeira (2009), in the case of higher education, an integrative approach to the term quality, expressed in its trans versatility with respect to the provision of institutions, is recurrent. To gauge the quality of the university presupposes a global approach to the functions of the university, which results, on the one hand, from the interconnections between them and, on the other, from the articulations of these functions with the other dimensions that make up the organization. With the implementation of a QMS in HEIs in Angola, based on ISO 9001:2015 (IPQ, 2015b), it is intended to make management more efficient, with impact on academic training, financial resources management, and human resources. With this implementation, we intend to continuously improve the quality of both the training offer and the services provided to the academic community. It can also be an important support for Institutional Marketing, for the external recognition that certification can bring, besides being a differentiating factor and influencing the attractiveness and notoriety of HEIs for teaching of recognized quality. 


\section{METHODOLOGY}

The impact evaluation of the implementation of ISO 9001 Standards in Angolan HEIs was conducted using a questionnaire. Fifty-five Angolan HEIs were selected from the 73 existing ones, which are part of the Statistical Yearbook of the Ministry of Higher Education, corresponding to $75 \%$ of the total (guaranteeing coverage of public and private HEIs). The questionnaire was sent by email. Fifty completed questionnaires were received, representing the sample of this work, representing a percentage of questionnaires answered and received about $91 \%$. From this sample, the AMOSTRAL database was built to support our work.

Table 1 - Main Questions of the Questionnaire

\begin{tabular}{|l|l|}
\hline Group of questions \\
\hline \multirow{3}{*}{$I^{o}$} & What is your role in the Institution? \\
\cline { 2 - 2 } & What is the educational system in which the institution is inserted? \\
\cline { 2 - 3 } Group & Does the Institution have the QMS implemented? \\
\cline { 2 - 2 } II $^{o}$ & Do you know the advantages of implementing QMS in HEIs? \\
\cline { 2 - 3 } & What is the benchmark you used as a basis for implementing the QMS in your HEIs? \\
\cline { 2 - 3 } & Which sectors of the institution where the QMS is implemented? \\
\hline
\end{tabular}

For the treatment of the data, the statistical analysis SPSS (Statistical Package for the Social Sciences) version 22.0 for Windows was used.

\section{RESULTS}

A total of 50 Angolan HEIs leaders participated in this study. The majority were male $(70 \%), n=35)$ whereas the female gender was represented by $30 \%(n=15)$ according to Fig. 1. Of the 50 Angolan HEIs surveyed, only $20 \%$ of them have the Quality Management System implemented, as can be seen in Fig. 1. We know this is little, but this is the Angolan reality. 


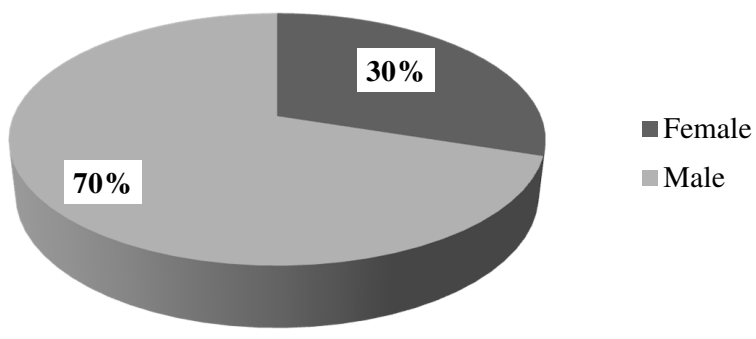

Figure 1 - Participants in the Survey about QMS

According to Fig. 2, the main reason for the non-implementation of the QMS is financial incapacity. Other reasons are: "a little institutional interest and availability of time". If organizations are more organized, then they will have more time to devote to problem-solving and quality improvement. It is a matter of organization.

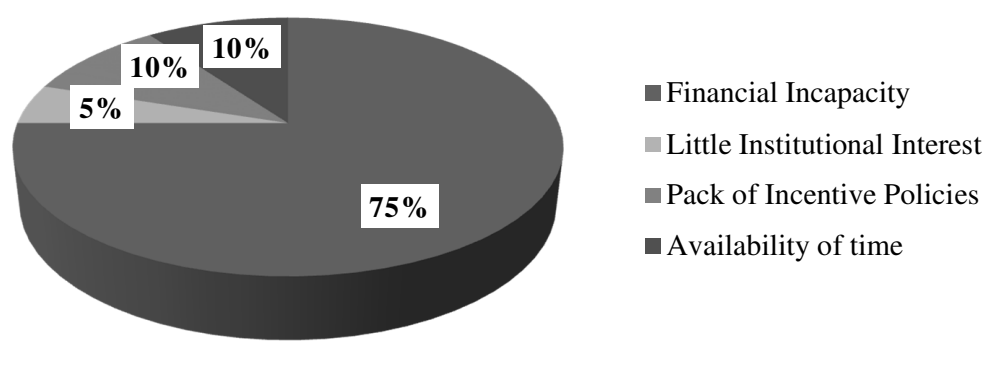

Figure 2 - Main Reasons for Non-Implementation of the QMS in HEIs

The respondents state that the implementation of the QMS was according ISO 9001, as can be seen in Fig. 3. Although there are other referential for implementing QMS, ISO 9001 is the most widely adopted.

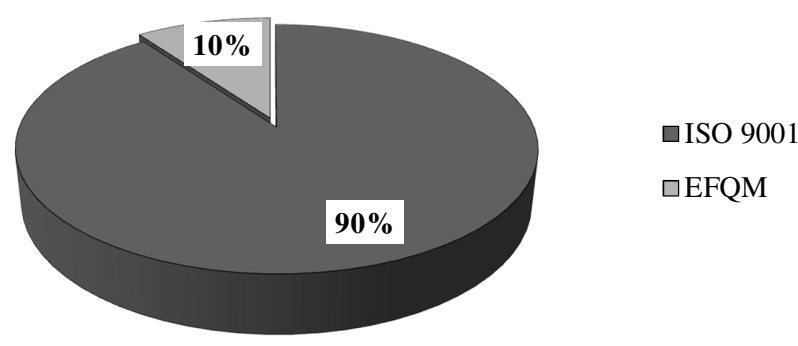

Figure 3 - The Referential More Used for the Implementation of the QMS in Angolan HEIs 
The difference of opinion between the respondents with Rector/Vice-Rectors and those with the functions of Director are all statistically significant, and those with a Director role are more in agreement with the statements related to the implementation of the QMS (see Tab. 2 and Fig. 4). Most statistical tests begin by identifying a null hypothesis. The null hypothesis for pattern analysis tools essentially states, that there is no spatial pattern among the features, or among the values associated with the features, in the study area. Said another way: the expected pattern is just one of the many possible versions of complete spatial randomness. The $\mathrm{Z}$ score is a test of statistical significance that helps you decide whether or not to reject the null hypothesis. The p-value is the probability that you have falsely rejected the null hypothesis. When a hypothesis test in statistics is performed, a p-value helps you determine the significance of the results. $\mathrm{Z}$ scores are measures of standard deviation and in Tab. 2 is decimal number. The 3 asterisks refer to person p of SPSS (Statistical Package for the Social Sciences), that is, when $\mathrm{p}<0.001$ the result is less.

Regarding the representativeness of the 'Rectors' and 'Directors' opinions, according to Tab. 2, it can be highlighted that it is important for Directors and Rectors to implement QMS. The Directors and the Rectors agree that it is important that higher education institutions in Angola implement the QMS (ANGOP, 2016).

Table 2 - Representativeness of Opinions Regarding the Implementation of the QMS between Rectors and Directors

\begin{tabular}{|l|c|c|c|c|c|}
\hline \multirow{2}{*}{} & \multicolumn{2}{|c|}{ Rectors } & \multicolumn{2}{c|}{ Directors } & \\
\cline { 2 - 6 } & $\mathrm{M}^{1}$ & $\mathrm{DP}$ & $\mathrm{M}$ & $\mathrm{DP}$ & $\mathrm{Z}^{3}$ \\
\hline $\begin{array}{l}\text { 1. It is important that higher education } \\
\text { institutions in Angola implement the } \\
\text { quality management system. }\end{array}$ & $\mathbf{5 . 2 1}$ & 1.48 & $\mathbf{6 . 9 7}$ & 0.17 & $-6.298^{* * * *}$ \\
\hline $\begin{array}{l}\text { 2. All Angolan higher education } \\
\text { institutions must have a certified quality } \\
\text { management system in place. }\end{array}$ & 4.50 & 1.40 & 6.75 & 0.44 & $-5.770^{* * * *}$ \\
\hline $\begin{array}{l}\text { 3. The Ministry of Higher Education of } \\
\text { Angola must create a legislative decree } \\
\text { that obliges higher education institutions } \\
\text { to implement the quality management } \\
\text { system. }\end{array}$ & 4.50 & 1.34 & 6.67 & 0.48 & $-5.448^{* * * *}$ \\
\hline $\begin{array}{l}\text { 4. Quality management enables higher } \\
\text { education institutions to improve the } \\
\text { quality of teaching. }\end{array}$ & 4.50 & 1.45 & 6.86 & 0.35 & $-6.016^{* * * *}$ \\
\hline
\end{tabular}




\begin{tabular}{|c|c|c|c|c|c|}
\hline & & & & tors & \\
\hline & $\mathrm{M}^{1}$ & $\mathrm{DP}^{2}$ & M & DP & $Z^{3}$ \\
\hline $\begin{array}{l}\text { 5. One of the main objectives of the } \\
\text { implementation of quality management in } \\
\text { higher education institutions has to do } \\
\text { with student satisfaction. }\end{array}$ & 4.79 & 1.48 & 6.81 & 0.40 & $-5.626 * * *$ \\
\hline $\begin{array}{l}\text { 6. The confidence of students and other } \\
\text { stakeholders in higher education is } \\
\text { established and maintained through } \\
\text { effective quality assurance activities. }\end{array}$ & 3.36 & 1.01 & 6.11 & 0.82 & $-5.584 * * *$ \\
\hline $\begin{array}{l}\text { 7. Institutional self-knowledge is the } \\
\text { starting point for effective quality } \\
\text { assurance. }\end{array}$ & 4.79 & 1.93 & 6.94 & 0.23 & $-6.051 * * *$ \\
\hline $\begin{array}{l}\text { 8. Students' evaluation is one of the most } \\
\text { important elements of their training } \\
\text { course in higher education. }\end{array}$ & 3.93 & 1.38 & 6.42 & 0.69 & $-5.410 * * *$ \\
\hline $\begin{array}{l}\text { 9. It is important that teachers of higher } \\
\text { education institutions in Angola have the } \\
\text { complete knowledge and understanding of } \\
\text { the area they teach. }\end{array}$ & 4.21 & 1.25 & 6.08 & 0.81 & $-4.781 * * *$ \\
\hline $\begin{array}{l}\text { 10. Teachers represent the most important } \\
\text { learning resource for most students in } \\
\text { higher education institutions in Angola. }\end{array}$ & 4.57 & 1.50 & 6.89 & 0.32 & $-6.112 * * *$ \\
\hline
\end{tabular}

Notes: *** $\leq 0.001 ; \mathrm{M}^{1}$ - Average; $\mathrm{DP}^{2}$ - Standard Deviation; $\mathrm{Z}^{3}$ - Statistically significant difference; $\mathrm{p}$ - decimal number; the 3 asterisks refer to person $\mathrm{p}$ (SPSS)

As main benefits of the implementation of the QMS in HEIs of Angola, it can be highlighted: Improvement the quality of teaching; Improvement of student satisfaction; Improvement of confidence of students and other stakeholders; Promotion of institutional self-knowledge for quality assurance; Improvement in student assessment; Improvement of teacher competences; Teachers as the most crucial resource of learning. Thus, according to Tab. 2, there are many work to do regarding improvement education in HEIs of Angola.

Fig. 4 shows the representativeness of opinions of Directors and Rectors. Directors deal more closely with the problems of teaching quality and organization. Thus, they have a more precise idea than that of the Rectors. These have to deal with other types of significant problems. 


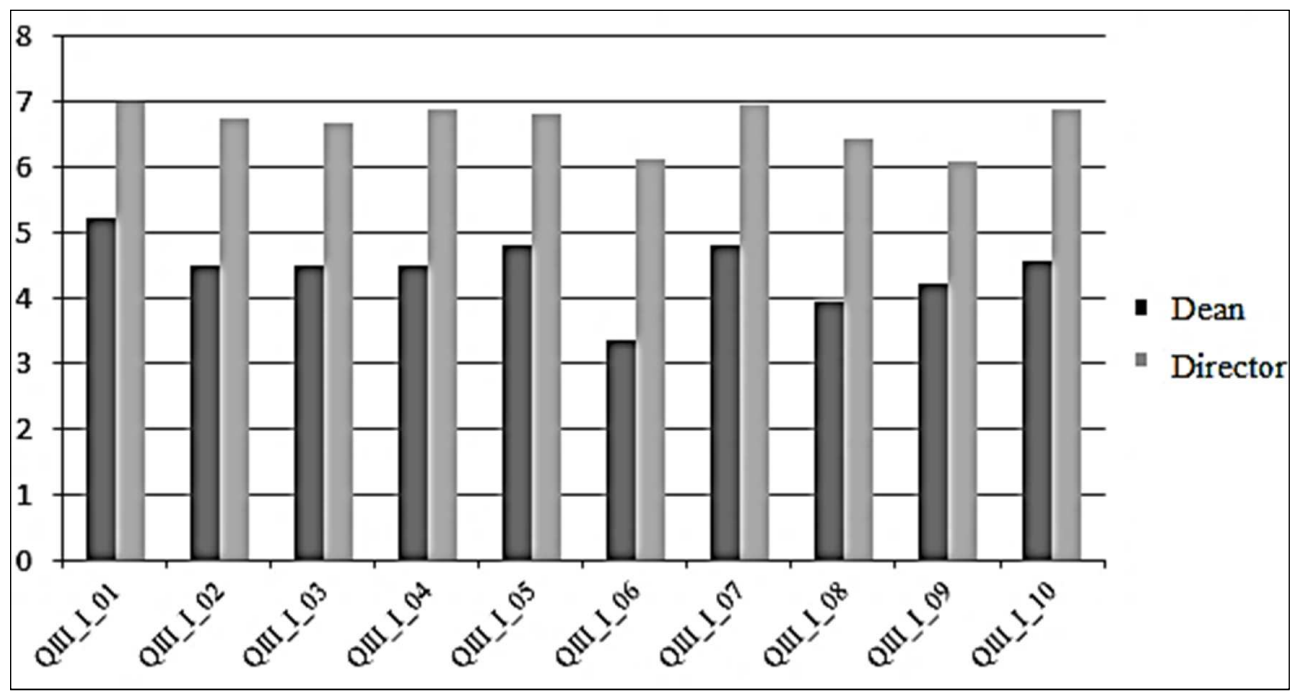

Figure 4 - Representativeness of the Views of the Implementation of the QMS between Rectors and Directors

When directors agree to implement QMS in their organizations, sooner or later, it will happen. This is the hope of many Angolans for a better education system.

\section{CONCLUSION}

Higher education in Angola has grown quantitatively over the last years. Still now there is a need to start looking for qualitative growth, which will imply the introduction of practices related to quality. Thus, the key to quality begins with changing the mindset of managers through knowledge, commitment, communication, and involvement. Nevertheless, it is necessary, in addition to changing the management mindset, a radical change in the mentality of all who are involved with the organization. The need arises for all members of the organization to work towards the same goal, towards the satisfaction of their clients, which in the specific case of Angolan HEIs are their students.

The results of the survey of Angolan HEIs show that most respondents are aware of the advantages of implementing the QMS, which is a significant step towards acieving it. It was found that the majority of the respondents who answered the questionnaire were the Directors to the detriment of the Rectors; on the other hand, it was concluded that one of the main reasons for not implementing the QMS is limited in the scarce financial resources that institutions have. Finally, it can be concluded that the Angolan HEIs recognize the advantages and are interested in the implementation of a QMS but have as main limitation the financial reasons, because the implementation of a QMS has high costs. 


\section{REFERENCES}

Agencia Angola Press (ANGOP), 2008. Discurso do Presidente José Eduardo dos Santos na tomada de posse do novo Governo. ANGOP, [online] 3 October. Available et: $<$ https://www.angop.ao/angola/pt_pt/noticias/politica/2008/9/40/Integradiscurso-Jose-Eduardo-dos-Santos-empossamento-novo-Governo,b2bea4338b1d-41ab-af75-d300f137d29a.html> [Accessed 28 November 2019].

Agencia Angola Press (ANGOP), 2016. Executivo aposta na Qualidade do Ensino Superior no Pais. ANGOP, [online] 26 August. Available et: $<$ https://m.portalangop.co.ao/angola/pt_pt/noticias/educacao/2016/7/34/AngolaExecutivo-aposta-qualidade-ensino-superior-pais,605e7272-ba9d-4b89-a5d99822ba0d7f8c.html> [Accessed 28 November 2019].

António, N.S. and Teixeira, A., 2009. Gestão da Qualidade - de Deming ao modelo de excelência da EFQM. Portugal: Edições Sílabo.

Araújo, R., Santos, G., Costa, J. and Sá, J.C., 2019. The Quality Management System as a Driver of Organizational Culture: An Empirical Study in the Portuguese Textile Industry. Quality Innovation Prosperity Journal, [e-journal] 23(1), pp.1-24. 10.12776/qip.v23i1.1132.

Batista, I. and Santos, G., 2015. O Impacto Financeiro das Auditorias da Qualidade nas Empresas Portuguesas. Revista Produção e Desenvolvimento, [ejournal] 1(3), pp.90-102. 10.32358/rpd.2015.v1.112.

Bravi, L., Murmura, F. and Santos, G., 2019. The ISO 9001:2015 Quality Management System Standard: Companies' Drivers, Benefits and Barriers to Its Implementation. Quality Innovation Prosperity Journal, [e-journal] 23(2), pp.6482. 10.12776/QIP.V23I2.1277.

Bruns, B., Macdonald, I.H. and Schneider, B.R., 2019. The politics of quality reforms and the challenges for SDGs in education. World Development, 118, pp.27-38.

Carvalho, F., Santos, G. and Gonçalves, J., 2018. The disclosure of information on Sustainable Development on the corporate website of the certified Portuguese organizations. International Journal of Quality Research, [e-journal] 12(1), pp.253-276. 10.18421/IJQR12.01-14.

Costa, A.R., Barbosa, C., Santos, G. and Alves, M.R., 2019. Six Sigma: Main Metrics and R Based Software for Training Purposes and Practical Industrial Quality Control. Quality Innovation Prosperity Journal, [e-journal] 23(2), pp.8399. 10.12776/QIP.V23I2.1278.

Dahlgaard-Park, S.M. and Dahlgaard, J.J., 2007. Excellence - 25 years evolution. Journal of Management History, 13(4), pp.371-393. 
Fey, R. and Gogue, J.M., 1983. Princípios da Gestão da Qualidade. Lisbon, Portugal: Fundação Calouste Gulbenkian.

Fonseca, L.M. and Domingues, J.P., 2018. Empirical Research of the ISO 9001:2015 Transition Process in Portugal: Motivations, Benefits, and Success Factors. Quality Innovation Prosperity Journal, [e-journal] 22(2), pp.16-46. 10.12776/QIP.V22I2.1099.

Ingason, H.T., 2015. Best Project Management Practices in the Implementation of an ISO 9001 Quality Management System. Procedia - Social and Behavioral Sciences, [e-journal]194, pp.192-200. 10.1016/j.sbspro.2015.06.133.

Instituto Português da Qualidade (IPQ), 2015a. Sistemas de Gestão da Qualidade Fundamentos e Vocabulário - ISO 9000:2015. Caparica, Portugal: IPQ.

Instituto Português da Qualidade (IPQ), 2015b. Sistemas de Gestão da Qualidade: Requisitos - ISO 9001:2015. Lisbon, Caparica, Portugal: IPQ.

Kotler, P. and Keller, K.L., 2006. Administração de Marketing. 12 ed. São Paulo: Pearson Prentice Hall.

Lee, P.K.C., To, W.M. and Yu, B.T.W., 2009. The implementation and performance outcomes of ISO 9000 in service organizations. An empirical taxonomy. International Journal of Quality \& Reliability Management, 26(7), pp.646-662.

Marques, C., Lopes, N., Santos, G., Delgado, I. and Delgado, P., 2018. Improving operator evaluation skills for defect classification using training strategy supported by attribute agreement analysis. Measurement, 119, pp.129141.

McAdam, R. and Canning, N., 2001. ISO in the service sector: perceptions of small professional firms. Managing Service Quality, 11(2), pp.80-92.

Murmura, F., and Bravi, L., 2017. Empirical evidences about ISO 9001 and ISO 9004 in Italian companies. The TQM Journal, [e-journal] 29(5), pp.650-665. 10.1108/TQM-11-2016-0097.

Pires, A.R., 2012. Sistema de Gestão da Qualidade - Ambiente, Segurança, Responsabilidade Social, Industria, Serviços, Administração Pública e Educação. Lisbon, Portugal: Sílabo.

Ribeiro, F., Santos, G., Rebelo, M. and Silva, R., 2017. Integrated Management Systems: trends for Portugal in the 2025 horizon. Procédia Manufacturing, [ejournal] 13, pp.1191-1198. 10.1016/j.promfg.2017.09.194.

Rodriguez-Mantilla, J.M., Fernandez-Diaz, M.J. and Carrascosa, V.L. 2019. Validation of a questionnaire to evaluate the impact of ISO 9001 Standards in schools with a Confirmatory Factor Analysis. Studies in Educational Evaluation 62, pp.37-48. 
Sánchez, I.M., Lupión, B.G. and González, D.G., 2017. What Do the Teaching Staff in Three Secondary Schools with ISO 9001/2008 Certification Think about the Quality of Diversity Improvement Plans?. Procedia - Social and Behavioral Sciences, [ejournal] 237, pp.237-241. 10.1016/j.sbspro.2017.02.069.

Santos, D., Rebelo, M. and Santos, G., 2017. The Integration of certified Management Systems. Case Study - Organizations located at the district of Braga, Portugal. Procédia Manufacturing, [e-journal] 13, pp.964-971. 10.1016/j.promfg.2017.09.168.

Santos, G. and Barbosa, J., 2006. QUALIFOUND - a modular tool developed for Quality Improvement in Foundries. Journal of Manufacturing Technology Management, [e-journal] 17(3), pp.351-362. 10.1108/17410380610648308.

Santos, G., Afonseca, J., Murmura, F., Félix, M.J. and Lopes, N., 2018. Critical success factors in the management of ideas as an essential component of innovation and business excellence. International Journal of Quality and Service Sciences, [e-journal] 10(3), pp.214-232. 10.1108/IJQSS-05-2017-0051.

Santos, G., Costa, B. and Leal, A., 2012. The Estimation of return on firms'investiments - as to ISO 9001. International Journal of Engineering, Science and Technology, 4(2), pp.46-57.

Santos, G., Doiro, M., Mandado, E. and Silva, R., 2019. Engineering learning objectives and computer assisted tools. European Journal of Engineering Education, [e-journal] 44(4), pp.616-628 10.1080/03043797.2018.1563585.

Santos, G., Mendes, F. and Barbosa, J., 2011. Certification and integration of management systems: the experience of Portuguese small and medium enterprises. Journal of Cleaner Production, [e-journal] 19(17-18), pp.1965-1974. 10.1016/j.jclepro.2011.06.017.

Santos, G. and Milán, A.L., 2013. Motivation and benefits of implementation and certification according ISO 9001 - The Portuguese experience. International Journal for Quality Research, 7(1), pp.71-86.

Santos, G., Murmura, F. and Bravi, L., 2019. Developing a model of vendor rating to manage quality in the supply chain. International Journal of Quality and Service Sciences, [e-journal] 11(1), pp.34-52. 10.1108/IJQSS-06-2017-0058.

Santos, G., Pais, M.S., Pereira, A.L. and Machado, V.C., 1996. Impact of quality certification in SMEs. In: EOQ (European Organization Quality), Proceedings of 40th EOQ Congress. Berlin, Germany, 10 September 1996. pp.131-140.

Santos, G., Ramos, D.G.G., Rodrigues, A.C. and Vale, P.E.L.F., 2008. Implementação de Sistemas Integrados de Gestão. Qualidade, Ambiente e Segurança (SIQAS). Porto, Portugal: Publindústria.

Secretaria de Estado do Ensino Superior (SEES), 2005. Linhas Mestras para a melhoria da gestão do subsistema do Ensino Superior. Luanda, Angola: SEES. 
Secretaria de Estado do Ensino Superior (SEES), 2007. Novos Rumos do Ensino Superior. Luanda: CDI-SEES.

Veiga, S.S., 2014. Implementação de um Sistema de Gestão da Qualidade - o caso da Camara Municipal de Aveiro. Master thesis. Universidade de Aveiro.

Weckenmann, A., Akkasoglu, G. and Werner, T., 2015. Quality management history and trends. The TQM Journal, [e-journal] 27(3), pp.281-293. 10.1108/tqm-11-2013-0125.

Zgodavova, K., Hudec, O. and Palfy, P., 2017. Culture of quality: insight into foreign organisations in Slovakia. Total Quality Management \& Business Excellence, [e-journal] 28(9-10), pp.1054-1075. 10.1080/14783363.2017.1309120.

Zgodavova, K., Zolotova, I. and Roznik, J., 2011. Creative Laboratory Engineering Education at Technical Faculties (The pilot project). In: ICL (Interactive Collaborative Learning), 14th International Conference on Interactive Collaborative Learning, Piešt'any, Slovakia, 21-23 September 2011. IEEE. pp.632-636. 10.1109/ICL.2011.6059663.

\section{ABOUT AUTHORS}

Nicolay Africano - is a Professor at the Polytechnic Institute of Kwanza Sul (ISPKS), Angola in the course of Accounting and Management, process Management and Management of Innovation and Entrepreneurshiop. He hold a M.Sc. degree in Organizational Management, Accounting and Management by the School of Technology and Management of the Polytecnic Institute Viana do Castelo. E-mail: nicolayafricano.aafricano@gmail.com.

Ana S. Rodrigues - is a Professor at the Polytechnic Institute of Viana do Castelo (IPVC), Portugal. She is Pro-president for Quality and Social Responsibility in IPVC and also IPVC Quality System Manager. Member of Auditing Team of Internal Quality Assurance Systems in Agency for Assessment and Accreditation of Higher Education. Member of the Advisory Board of the Agency for Quality Assurance in the Galician University System. Member of Sectorial Commission for Education and Training of Portuguese Quality Institute. Lead Auditor ISO 22000 and ISO 9001 by International Register of Certified Auditors (IRCA). Research Associate Member in the Centre for Research and Development in Agrifood Systems and Sustainability-IPVC. She holds a PhD in Quality, Safety and Food Technology by the Vigo University, Spain. E-mail: sofia@ipvc.pt, Author's ORCID: 0000-0001-5268-6102. 
Gilberto Santos - is Professor at the Polytechnic Institute Cávado Ave (IPCA), Barcelos, Portugal, where he founded a master's course on "Integrated Management Systems QES (Quality, Environment and Safety) and was the director of it for 7th editions. He holds an Aggregation (DSc) title in Industrial Engineering from de New University of Lisbon and a PhD degree in Mechanical Engineering from the Minho University, Portugal. He participates as a Speaker in several national and international conferences and is the author of several publications, reviewer for International Journals. E-mail: gsantos@ipca.pt, Author's ORCID: 0000-0001-9268-3272.

Conflicts of Interest: The authors declare no conflict of interest.

(C) 2019 by the authors. Submitted for possible open access publication under the terms and conditions of the Creative Commons Attribution (CC-BY) license (http://creativecommons.org/licenses/by/4.0/). 